\title{
Bibliography of printed works cited
}

Robert Alter, Frank Kermode, eds, The literary guide to the Bible, London, 1987.

Augustine, Saint, The City of God, trans. John Healey, ed. R. V. G. Tasker, 2 vols, London, 1945.

Fritz (Yitzhak) Baer, Die Juden im christlichen Spanien, Berlin, 1929, 1936, reprinted 1970 .

Malcolm Barber, The two cities. Medieval Europe, 1050-1320, London, 1992.

Haim Beinart, Trujillo. A Jewish community in Extremadura on the eve of the expulsion from Spain, Hispania Judaica, II, Jerusalem, 1980.

Eloy Benito Ruano, Los orígenes del problema converso, Barcelona, 1976.

Andrés Bernáldez, Memorias de los Reyes Católicos, ed. M. Gómez-Moreno and J. de M. Carriazo, Madrid, 1962.

Biblia sacra iuxta vulgatam clementinam, ed. Alberto Colunga, O.P. and Laurentio Turrado, Madrid, 1977.

P. R. L. Brown, Augustine of Hippo, London, 1967.

Jean Calvin, Institution de la religion Chrestienne, ed. Jean-Daniel Benoît, Paris, 1957.

Dwayne E. Carpenter, Alfonso X and the Jerws: an edition of and commentary on 'Siete Partidas' 7: 24, 'De los judios', Modern Philology, CXV, Berkeley, Los Angeles, London, 1986.

Carlos Carrete Parrondo, El tribunal de la Inquisición en el obispado de Soria (14861502), Fontes Iudaorum Regni Castello, II, Salamanca, 1985.

Carlos Carrete Parrondo and Carolina Fraile Conde, Los judeoconversos de Almazán, 1501-1505. Origen familiar de los Lainez, Fontes Iudeorum Regni Castella, IV, Salamanca, 1987.

William A. Christian, Jr, Local religion in sixteenth-century Spain, Princeton, 1981.

Jeremy Cohen, The friars and the Jews. The evolution of medieval anti-Judaism, Ithaca and London, 1982.

Roger Collins, Early medieval Spain. Unity in diversity, 400-1000, London, 1983.

Rafael Conde and Delgado de Molina, La expulsión de los Judios de la Corona de Aragón. Documentos para su estudio, Zaragoza, 1991.

Elvira Cunha de Azevedo Mea, 'Oraçiones judaicas na Inquisição Portuguesaseculo XVI', in Yosef Kaplan, ed., Jews and Conversos. Studies in society and the Inquisition, Jerusalem, 1985, pp. 149-78.

Francisco Delicado, La Lozana andaluza, ed. Bruno Damiani, Madrid, 1982.

Le dictionnaire des inquisiteurs, ed. Luis Sala-Molins, Paris and the Hague, 1978.

Eamon Duffy, The stripping of the altars. Traditional religion in England, 1400-1580, New Haven and London, 1992.

John Edwards, 'The conversos: a theological approach', Bulletin of Hispanic Studies, LXII, 1985, pp. 39-49. 
John Edwards, 'Conversos, Judaism and the language of monarchy in fifteenthcentury Castile', in Circa 1492. Proceedings of the Jerusalem Colloquium: Littere Judarum in Terra Hispanica, ed. Isaac Benabu, Jerusalem, 1992, pp. 207-23.

John Edwards, 'Debate. Religious faith, doubt and atheism', Past and Present, 128, 1990, pp. $158-60$.

John Edwards, The Jews in Christian Europe, 1400-1700, London, 1988, rev edn 1991.

John Edwards, "Male and female religious experience among Spanish "New Christians", 1450-1500', in The expulsion of the Jews: 1492 and after, ed. Raymond B. Waddington and Arthur Williamson, New York and London, pp. 41-51.

John Edwards, 'Religious faith and doubt in late medieval Spain: Soria circa 14501500', Past and Present, 120, 1988, pp. 3-25.

John Edwards, 'Why the Spanish Inquisition?', Studies in Church History, XXIX, Christianity and Judaism, 1992, pp. 221-36.

Erasmus, Collected works of, various editors, Toronto, 1974-.

Nicolau Eymerich, Le manuel de l'Inquisiteur, with additions by Luis Peña, ed. Luis Sala-Molins, Paris and The Hague, 1977.

Fidel Fita, 'La verdad sobre el martirio del Santo Niño de La Guardia, o sea el proceso y quema (16 noviembre 1491) del judío Juçe Franco de Avila', Boletín de la Real Academia de la Historia, Xl, 1887, pp. 7-160.

John Gager, The origins of anti-Semitism, New York, 1983.

L. Geiger, ed., Johann Reuchlins Briefwechsel, Stuttgart, 1875.

Damião de Gois, Cronica do felicissimo Rei Don Manuel, in Damião de Gois, ed. Antonio Alvaro Doria, Lisbon, 1944.

Damião de Gois, Cronica de Don Manuel, ed. Rodrigues Lapa, in Historiadores quinhentistas, Lisbon, 1972.

Rafael Gracia Boix, Colección de documentos para la historia de la Inquisición de Córdoba, Córdoba, 1981.

Solomon Grayzel, The Church and the Jews in the thirteenth century, Philadelphia, 1933.

Bernard Gui, Le manuel de l'Inquisiteur, ed. G. Mollat, 2 vols, Paris, 1964.

Bernard Hamilton, The medieval Inquisition, London, 1981.

Sebastián de Horozco, La historia del niño inocente de La Guardia, in Jack Weiner, ed., Relaciones históricas toledanas, Toledo, 1981, pp. 29-38.

Pier Cesare Ioly Zorattini, Processi del S. Uffizio di Venezia contro Ebrei e Giudaizzanti (1548-1560), 3 vols, Florence, 1980-1984.

Jonathan Israel, European Jewry in the age of mercantilism, 1550-1750, Oxford, 1987.

William James, The varieties of religious experience, Cambridge, Mass., 1985.

Ann Jefferson and David Robey, Modern literary theory. A comparative introduction, London, 1982.

Jerusalem Bible, The, ed. Alexander Jones, London, 1968.

W. C. Jordan, The French monarchy and the Jews. From Philip Augustus to the last Capetians, Philadelphia, 1989. 
Yosef Kaplan, ed., Jews and conversos. Studies in society and the Inquisition, Jerusalem, 1985.

Leszek Kolakowski, Religion: if there is no God, Glasgow, 1982.

Gavin I. Langmuir, History, religion and Antisemitism, Berkeley, Los Angeles and Oxford, 1990.

Gavin I. Langmuir, Toward a definition of Antisemitism, Berkeley, Los Angeles, Oxford, 1990.

Nicholas Lash, Easter in ordinary. Reflections on human experience and the knowledge of God, London, 1988.

Renée Levine [Melamed], 'Women in Spanish crypto-Judaism, 1492-1520', unpublished Ph.D. thesis, Brandeis, 1982.

Jerzy Lukowski, Liberty's folly. The Polish Lithuanian Commonwealth in the eighteenth century, London, 1991.

Martin Luther, Luther's works, vol. XLV, ed. and trans. Walther I. Brandt, Philadelphia, 1962, and vol. XLVII, ed. and trans., Franklin Sherman, Philadelphia, 1971.

Michele Luzzati, La casa dell'Ebreo. Saggi sugli Ebrei a Pisa e in Toscana nel Medioevo e nel Rinascimento, Cultura e Storia Pisana, 7, Pisa, 1985, pp. 49-57, and 203-34.

Hyam Maccoby, Judaism on trial. Jewish-Christian disputations in the Middle Ages, London and Toronto, 1982.

Eleanor McLaughlin, 'Women, power and the pursuit of holiness in medieval Christianity', in Feminist theology. A reader, ed. Ann Loades, London, 1990, pp. 99-123.

J. D. Mansi, Sacrorum conciliorum nova et amplissima collectio, Florence, 1759-1798, reprinted 1962.

Thérèse and Mendel Metzger, Jewish life in the Middle Ages. Illuminated Hebrew manuscripts of the thirteenth to sixteenth centuries, New York 1982.

Leon Modena, The autobiography of a seventeenth-century Venetian rabbi. Leon Modena's 'Life of Judah', trans. and ed. Mark R. Cohen, Princeton, 1988.

Yolanda Moreno Koch, ed., De iure hispano-hebraico. Las taqqanot de Valladolid de 1432. Un estatuto comunal renovador, Fontes Iudoorum Regni Castello, V, Salamanca, 1987.

Colin Morris, The Papal monarchy: the Western Church, 1050-1250, Oxford, 1988.

Moisés Orfali Levi, Los conversos españoles en la literatura rabinica. Problemas jurídicos y opiniones legales durante los siglos XII-XVI, Salamanca, 1982.

Otto of Freising, The two cities. A chronicle of universal history to the year 1146 A.D., trans. C. C. Mierow, New York, 1966.

Amilcar Paulo, 'O ritual dos criptojudeus portugueses (algumas reflexões sobre os seus ritos)', in Yosef Kaplan, ed., Jews and conversos. Studies in society and the Inquisition, Jerusalem, 1985, pp. 139-48.

Maria José Pimenta Ferro Tavares, Judaismo e Inquisição. Estudos, Lisbon, 1987.

Brian Pullan, The Jews of Europe and the Inquisition of Venice, 1550-1670, Oxford, 1983.

Johann Reuchlin, On the art of the Kabbalah [De arte Cabalistica], ed. and trans. 
Martin and Sarah Goodman, New York, 1983.

Ellis Rivkin, 'How Jewish were the New Christians?', in Josep M. Solà, Samuel G. Armistead and Joseph H. Silverman, eds, Hispania Judaica: studies on the history, language and literature of the Jews in the Hispanic world, I, History, Barcelona, 1980, pp. 105-15.

Ellis Rivkin, 'The utilisation of non-Jewish sources for the reconstruction of Jewish history', Jewish Quarterly Review, XLVIII, 1957-8, pp. 183-203.

Mark Saperstein, Jewish preaching, 1200-1800, New Haven and London, 1989.

Shlomo Simonsohn, The Apostolic See and the Jerws, 8 vols, Toronto, 1988-1991.

Shlomo Simonsohn, The Jews of the duchy of Milan, 4 vols, Jerusalem, 1982-1986.

C. John Sommerville, 'Debate. Religious faith, doubt and atheism. Comment', Past and Present, 128, 1990, pp. 152-5.

George Steiner, After Babel. Aspects of language and translation, Oxford, 1975, 1993.

Luis Suárez Fernández, Documentos acerca de la expulsión de los Judios, Valladolid, 1964.

R. N. Swanson, Catholic England. Faith, religion and observance before the Reformation, Manchester, 1993.

R. N. Swanson, 'Medieval liturgy as theatre: the props', Studies in Church History, XXIX 1992, pp. 239-53.

Carsten Peter Thiede, Heritage of the first Christians. Tracing early Christianity in Europe, trans. Knut Hein, Oxford, 1992.

C. R. Thompson, trans., The Colloquies of Erasmus, Chicago, 1965.

B. Tierney, The crisis of Church and state, 1050-1300, Englewood Cliffs, N.J., 1964.

Ariel Toaff, The Jews in Umbria, I, 1245-1435, Leiden, 1993.

Joshua Trachtenberg, The Devil and the Jews, New Haven, 1943.

Walter Ullmann, A short history of the Papacy in the Middle Ages, London, 1972.

W. A. Wakefield, Heresy, Crusade and Inquisition in southern France, 1100-1250, London, 1974.

Benedicta Ward, 'Saints and sybils: Hildegard of Bingen to Teresa of Avila', in After Eve. Women, theology and the Christian tradition, ed. Janet Martin Soskice, London, 1990, pp. 103-18. 